соответствует депрессивной фазе процесса отравления, а при 10 мг/дм³ этого поллютанта у них быстро следуют одна за другой завершающие его фазы - сублетальная и летальная.

Эти моллюски могут быть использованы в качестве индикаторных видов в системе экологического мониторинга.

Ключевые слова: перловицевые, купрум сульфат, ритм сердцебиения.

Stadnychenko Agnessa, Vyskushenko Dmytro. The Influence of Cuprum Sulphate of Water Environment on Unionides (Mollusca, Bivalvia, Unionidae) Heart Beat Frequency. The article focuses on the influence of the different concentrations $\left(0,1,1,10 \mathrm{mg} / \mathrm{dm}^{3}\right)$ cuprum sulfate of water environment on physiological state of Unio conus, U. rostratus, Colletopterum piscinale - the most widespred and numerous species from unionides in Ukraine. The heart beat frequency obtain visually from the fistulary animals have been used as the test-function. In solution which contain $0,1 \mathrm{mg} / \mathrm{dm}^{3}$ cuprum sulfate heart beat frequency sharply raisees in all reserched species. It is one from the protective compensatory adaptation correspond to the phase stimulation of poisoning process. With cuprum sulfate concentrations increase to $1 \mathrm{mg} / \mathrm{dm}^{3}$ bradycardia becomes evident in these animals. It sharply progresses if cuprum sulfate concentration increase to $10 \mathrm{mg} / \mathrm{dm}^{3}$. With $1 \mathrm{mg} / \mathrm{dm}^{3}$ cuprum sulfate physiological state of unionides corresnond to depressive phase of poisoning process. With $10 \mathrm{mg} / \mathrm{dm}^{3}$ this matter in environment result in the rapid go after of two last phases of poisoning process - sublethal and lethal.

These unionides maybe use in the ecological monitoring system as species-indicators.

Key words: unionides, cuprum sulphate, heart rhythm.

Стаття надійшла до редколегії 06.09.2015 p.

УДК 595.745/502.7(477-924.52)

Катерина Сухомлін,

Василь Чумак,

Анна Омелянчук

\title{
Аналіз видового складу імаго волохокрильців (Trichoptera) Угольського заповідного масиву Карпатського біосферного заповідника
}

У межах Угольського заповідного масиву Карпатського біосферного заповідника зареєстровано 10 видів волохокрильців із восьми родів. Домінантним і розповсюдженим є Limnephilus rhombicus. Імаго волохокрильців активно літають із квітня до середини серпня. Найвищу активність льоту зареєстровано із середини квітня до початку червня. Упродовж решти вегетаційного сезону імаго трапляється в невеликій кількості. Найбільшу кількість видів (60 \%) відзначено в лісі, а найменшу (40\%) - на межі лісу та вікна. Найбільшу кількість особин різних видів зареєстровано в центрі вікна (50 \%), а найменшу $(22,3 \%)$ - у лісі. Зі збільшенням висоти ділянок над рівнем моря зростає видовий склад, а чисельність зібраних імаго знижується. Експозиція схилу впливає на видовий склад імаго волохокрильців. Так, Halesus digitatus зареєстровані лише на північних схилах, Ironoquia dubia - на південних, Rhyacophila nubila - при східній експозиції схилу.

Ключові слова: Trichoptera, видове різноманіття, поширення, Угольський заповідний масив, Карпатський біосферний заповідник.

Постановка наукової проблеми та її значення. Волохокрильці - відносно невеликий ряд гетеротопних комах. Вони відіграють важливу роль у біоценозах, оскільки личинки й лялечки, а також i дорослі особини слугують кормом для різних риб та птахів. Личинки волохокрильців у прісних водоймах становлять істотну частину бентосу й можуть бути використані під час біологічного аналізу води як індикаторні організми рівня забруднення. Здебільшого личинки волохокрильців є олігосапробами мешканцями чистої води [1].

Аналіз дослідження цісї проблеми. Перші згадки про волохокрильців (Trichoptera) України простежено в роботі Г. Белке [7]. Науковець, порівнюючи фауну Поділля й Карпат, називає чотири види, які мешкають у Карпатах: Phryganea grandis, Agrypnia varia, Limnephilus rhombicus, Anabolia laevis. Польський ентомолог Я. Дзідзелевич зареєстрував на території Східних Карпат і Прикарпаття

(C) Сухомлін К., Чумак В., Омелянчук А., 2015 
184 види волохокрильців, із яких сім описано ним уперше [8-10]. Подальші тріхоптерологічні дослідження в Українських Карпатах відновленно на початку 60-х років XX ст. А. Я. Балогом [1]. У результаті обробки зібраного матеріалу визначено 38 видів, що належать до шести родин: Rhyacophilidae, Hydroptilidae, Hydropsychidae, Odontoceridae, Limnophilidae, Sericostomatidae. H. Н. Данко [2-4] систематизував весь накопичений за багато років практичний і теоретичний матеріал щодо фауни волохокрильців Українських Карпат. За його дослідженнями наведено 190 видів, котрі належали до 18 родин: Rhyacophilidae, до якої входили 13 видів, Glossosomatidae - вісім, Hydroptilidae - шість, Philopotamidae - сім, Ecnomidae - один, Polycentropodidae - 10, Psychomyidae - чотири, Hydropsychidae 11, Phryganeidae - дев'ять, Brachycentridae - чотири, Goeridae - шість, Lepidostomatidae - три, Limnephilidae - 76 видів, Sericostomatidae - чотири, Odontoceridae - один, Molannidae - два, Beraeidae три, Leptoceridae - 20 видів [4].

Мета роботи - проведення еколого-фауністичного аналізу імаго волохокрильців у біотопах Угольського заповідного масиву.

Матеріал та методика дослідження. Матеріалом для досліджень слугували збори, отримані впродовж 2011 р. за українсько-швейцарським проектом «Effect of canopy gaps on species assemblages of saproxylic beetles in the UholkaForest, Ukraine» в Угольському заповідному масиві Карпатського біосферного заповідника.

Усього проаналізовано 47 проб і досліджено 130 екземплярів імаго волохокрильців. Для збору матеріалу використовували комбіновані пастки (рис. 1). Вони складались із лійки жовтого кольору діаметром 90 см, зверху якої кріпились дві перпендикулярні прозорі пластини 3 оргскла. Лійку заповнювали фіксуючою рідиною й кріпили на підставках на висоті одного метра.
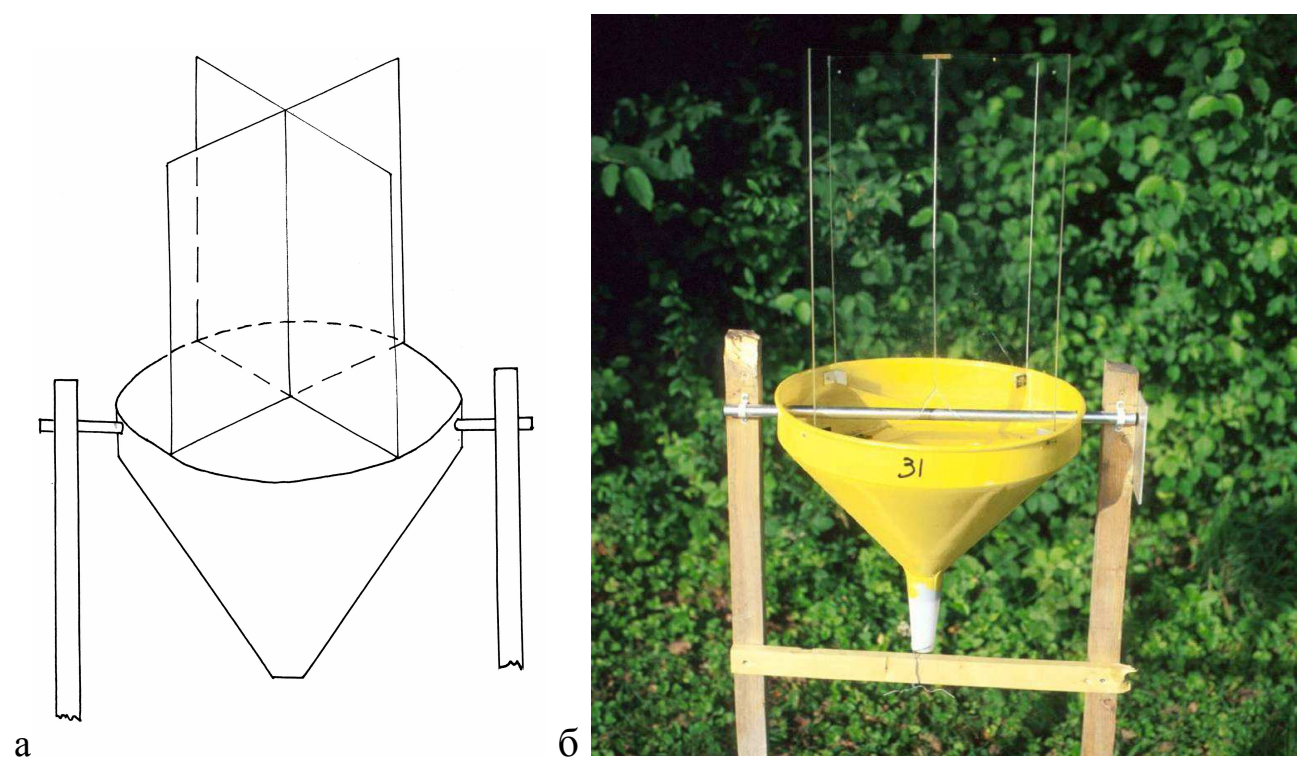

Рис. 1. Комбінована пастка з діаметром 90 см: а-схема, б-фото

Пастки встановлювали на 20 постійних пробних площах, об’єднаних у п’ять дослідних ділянок (рис. 2). Вони розміщувалися в межах однієї площадки на відстані мінімум 10 м одна від одної. Пастки функціонували протягом вегетаційного сезону з початку вегетації до кінця вересня. Матеріал із пасток вилучали кожні 10 днів. Потім його фіксували в 70 \% спирті (етанолі).

Для ідентифікації використовували визначники С. Г. Лепньової [5; 6].

Дослідні ділянки - «вікна» в наметі лісу (галявини), які утворилися в результаті вивалу окремих дерев або вітровалу. У межах кожного вікна встановлювали три пастки.

«Центр»- територія, розміщена в центрі вікна (точка перетину найдовших осей, кут яких становить $90^{\circ}$ ). «Екотон» - територія на межі лісу й галявини. «Контроль» - територія, розміщена під наметом лісу. Тобто виставлено 60 пасток (20х3). 


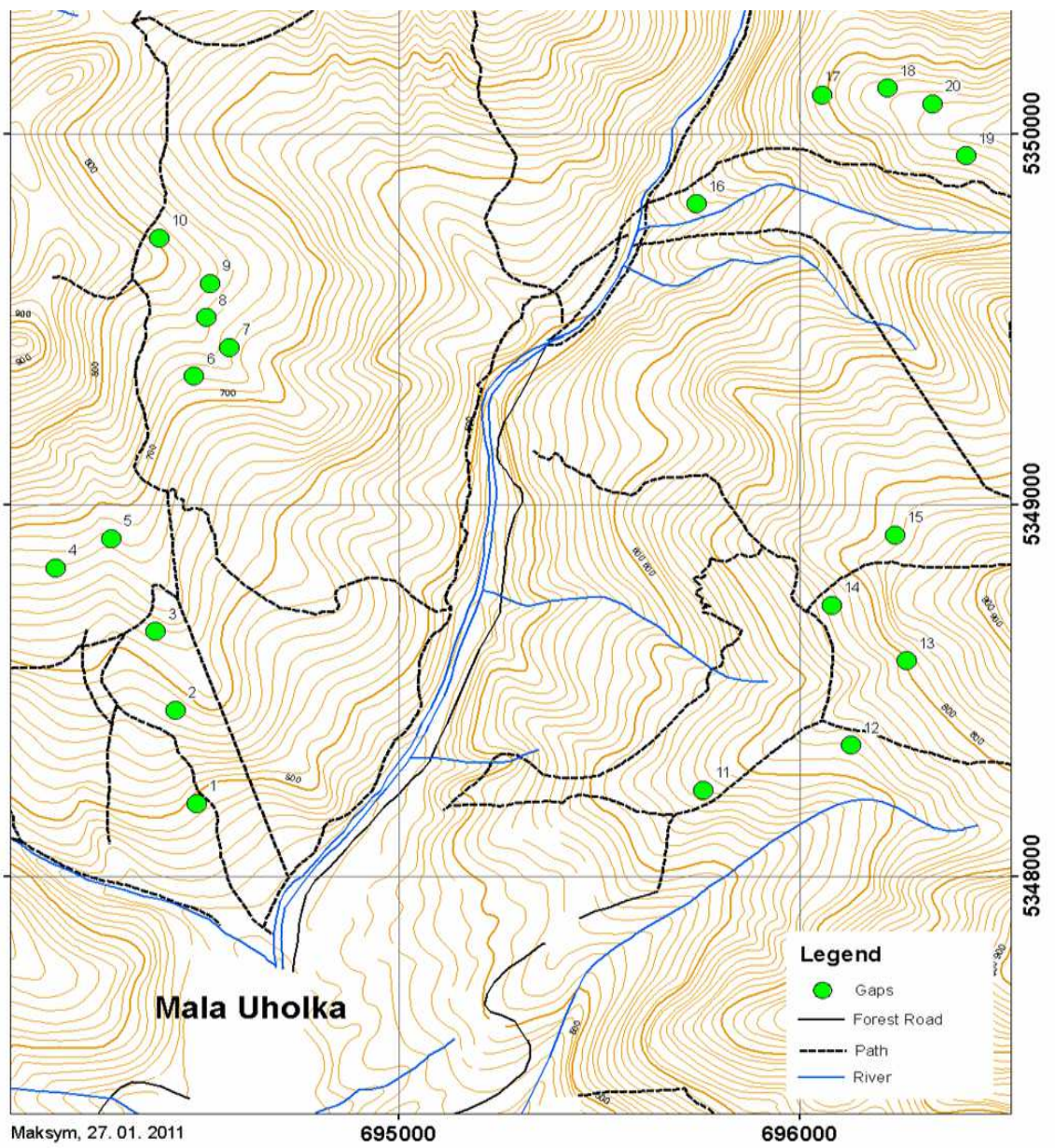

Рис. 2. Карта-схема території дослідження з нанесеними місиями збору матеріалу

Виклад основного матеріалу й обгрунтування отриманих результатів дослідження. На території Угольського заповідного масиву Карпатського біосферного заповідника зареєстровано 10 видів волохокрильців із восьми родів (табл. 1).

Таблиия 1

Відносна чисельність заресстрованих видів

\begin{tabular}{|l|c|c|}
\hline \multicolumn{1}{|c|}{ Назва виду } & ІД, $\%$ & ІІ, $\%$ \\
\hline Limnephilus rhombicus (Linnaeus, 1758) & 53,3 & 63,9 \\
\hline Limnephilus flavicornis (Fabricius, 1787) & 8,3 & 12,8 \\
\hline Limnephilus griseus (Linnaeus, 1758) & 5,6 & 6,4 \\
\hline Glyphotaelius pellucidus (Retzius, 1786) & 5,0 & 4,6 \\
\hline Potamophylax rotundipennis (Brauer, 1857) & 13,4 & 27,6 \\
\hline Halesus digitatus (Curtis, 1834) & 3,4 & 6,4 \\
\hline Rhyacophila nubile (Zetterstedt, 1840) & 1,4 & 2,1 \\
\hline Anabolia brevipennis (Curtis, 1834) & 2,3 & 4,2 \\
\hline Ironoquia dubia (Curtis, 1834) & 2,3 & 2,1 \\
\hline Grammotaulius nitidus (Muller, 1830) & 5,0 & 8,5 \\
\hline \multicolumn{1}{|c|}{ Разом } & 100 & - \\
\hline
\end{tabular}

Домінантним видом на території Угольського заповідного масиву є Limnephilus rhombicus (IД 53,3 \%), численним - Potamophylax rotundipennis (ІД - 13,4 \%), нечисленні (ІД - 1,4-8,3 \%) Limnephilus flavicornis, Limnephilus griseus, Glyphotaelius pellucidus, Halesus digitatus, Rhyacophila nubile, Anabolia brevipennis, Ironoquia dubia, Grammotaulius nitidus. 
На території Угольського заповідного масиву розповсюдженим (IП - 63,9\%) видом виявився Limnephilus rhombicus, поширеними (IП - 12,8-27,6 \%) - Potamophylax rotundipennis та Limnephilus flavicornis. Непоширеними (IП - 6,4-8,5 \%) є Limnephilus griseus, Halesus digitatus, Grammotaulius nitidus, локальне поширення (IП - 2,1-4,6 \%) мають Ironoquia dubia, Anabolia brevipennis, Rhyacophila nubile, Glyphotaelius pellucidus.

У ході досліджень нами помічено зміни активності льоту волохокрильців із травня до серпня (рис. 3).

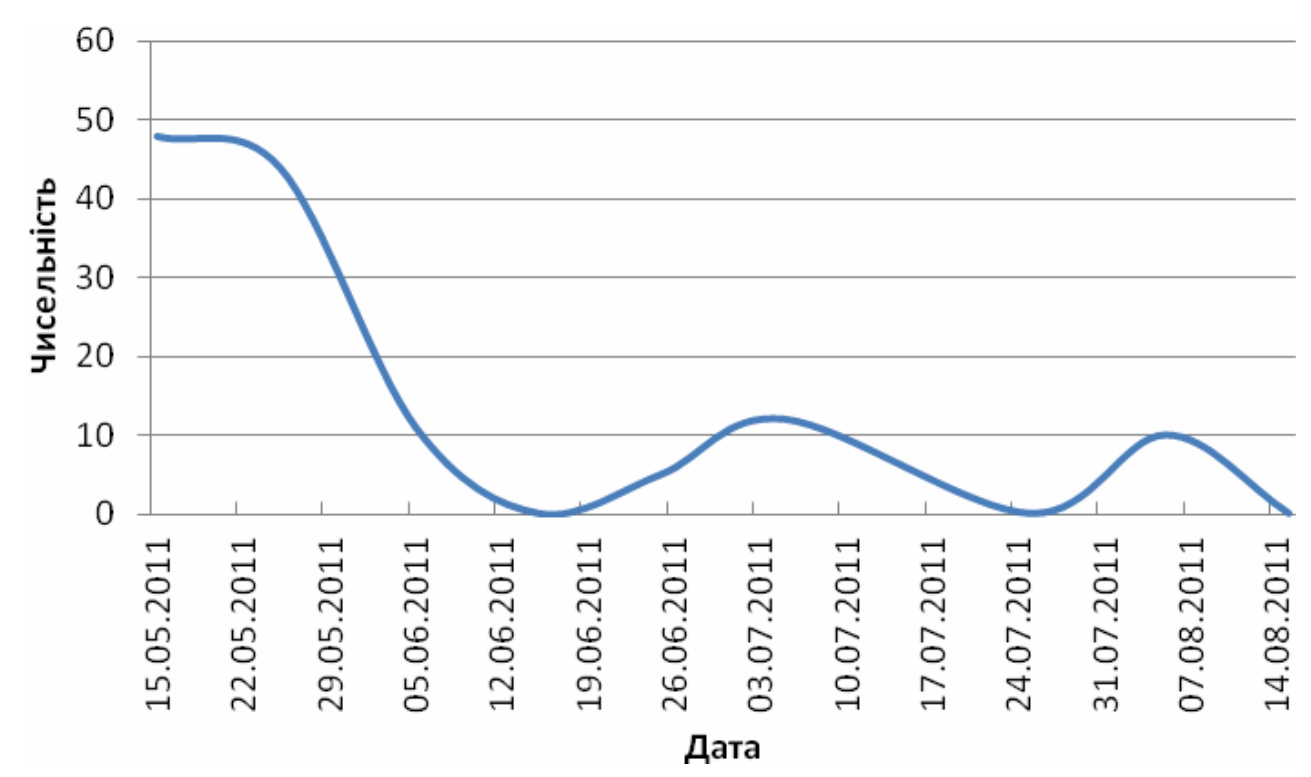

Рис. 3. Сезонна динаміка волохокрильців на території Угольського заповідного масиву Карпатського біосферного заповідника

Найбільшу кількість імаго волохокрильців зібрано в II та III декадах травня (відповідно, 48 та 44 особини). Далі, упродовж теплого періоду, у пастки потрапляли лише поодинокі особини в кількості 10-12 особин, що свідчить про зменшення активності льоту всіх видів із середини червня. Отже, активність льоту зменшується приблизно в чотири рази. Упродовж періоду досліджень 15.06.2011 та 25.07.2011 у пастки не потрапило жодного волохокрильця, що може опосередковано свідчити про зміну видового складу імаго (одні види завершили літ, а інші ще не почали).

У II і III декадах травня відзначено не лише високу чисельність, але й найбільше видове різноманіття. У пастки потрапляли всі 10 зареєстрованих видів. У червні та липні літають по три види, а в серпні лише два.

Імаго волохокрильців активно літають із квітня до середини серпня (рис. 4). Найвищу активність льоту зареєстровано в середині квітня, вона триває до початку червня. Упродовж решти вегетаційного сезону імаго трапляється в невеликій кількості.

У квітні та травні активні імаго 10 видів волохокрильців: Limnephilus rhombicus, Limnephilus flavicornis, Limnephilus griseus, Glyphotaelius pellucidus, Potamophylax rotundipennis, Halesus digitatus, Rhyacophila nubila, Anabolia brevipennis, Ironoquia dubia та Grammotaulius nitidus. У червні літають представники трьох видів: Limnephilus rhombicus, Potamophylax rotundipennis, Grammotaulius nitidus. У липні зареєстровано представників трьох видів: Limnephilus rhombicus, Limnephilus griseus, Potamophylax rotundipennis. У серпні виявлено лише два види: Limnephilus rhombicus та Potamophylax rotundipennis.

Із квітня до травня активні імаго трьох видів волохокрильців: Limnephilus flavicornis, Glyphotaelius pellucidus i Ironoquia dubia. Лише в травні зареєстровано імаго Halesus digitatus, Rhyacophila nubile, Anabolia brevipennis. Із травня до червня активні імаго Grammotaulius nitidus. Із травня до липня літають імаго Limnephilus griseus. Із травня до серпня зареєстровано активність імаго двох видів: Limnephilus rhombicus тa Potamophylax rotundipennis. 
РОЗДІЛ ІІ. Зоологія. 12, 2015

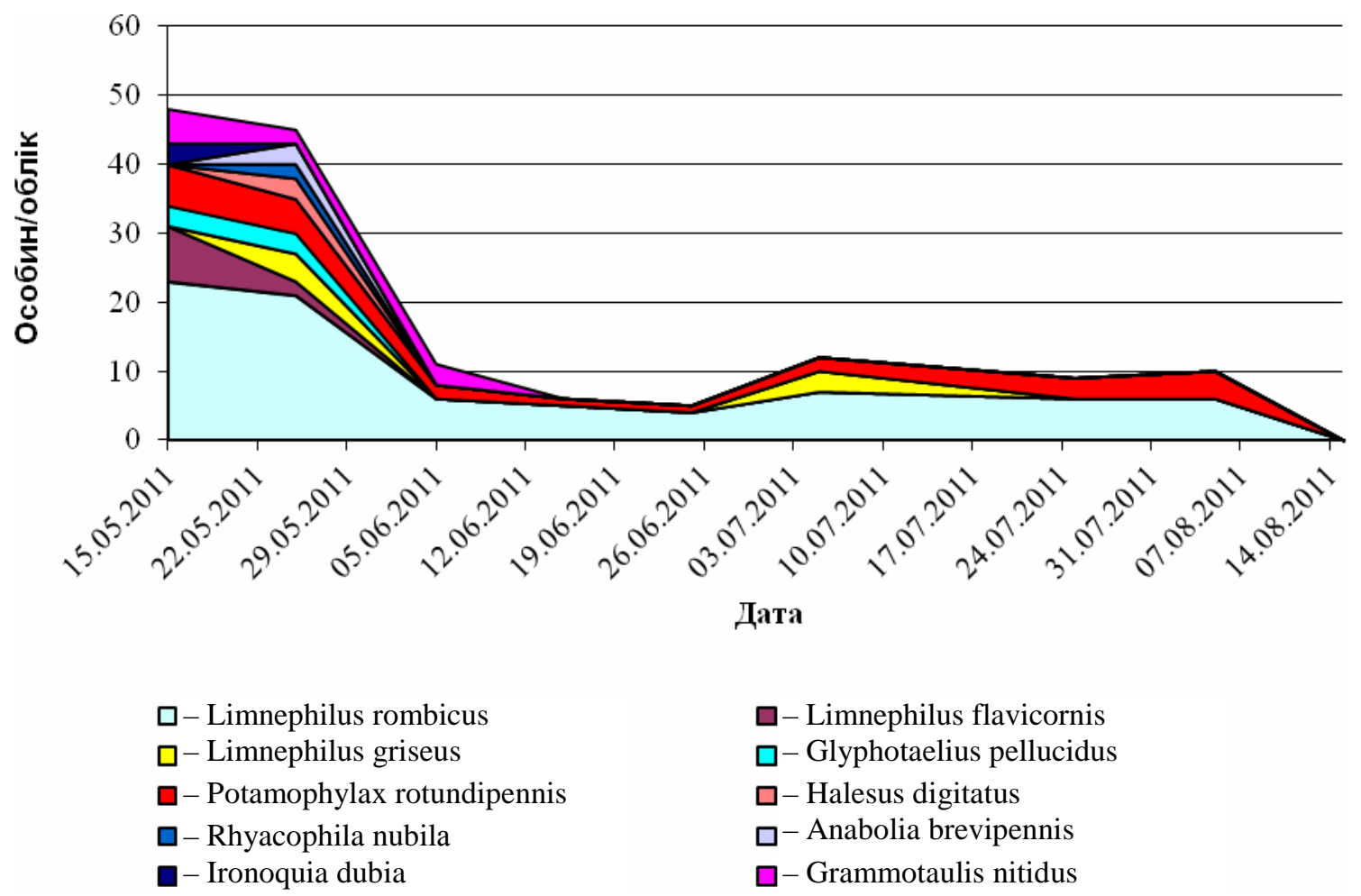

Рис. 4. Сезонна динаміка зареєстрованих видів волохокрильиів на території Угольського заповідного масиву

Аналізуючи чисельність і поширення видів волохокрильців у різних біотопах досліджуваних ділянок, установили, що в центрі вікон на вільних від рослинності ділянках загалом трапляється п'ять видів: Limnephilus rombicus, Potamophylax rotundipennis, Grammotaulis nitidus, Glyphotaelius pellucidus, Halesus digitatus, серед яких два останніх виявлено лише в цьому біотопі. У центрі відловлено найбільшу кількість особин 65 (50,0 \%) зі 130 зібраних (табл. 2).

Табличя 2

Чисельність видів волохокрильців у різних біотопах досліджуваних ділянок

\begin{tabular}{|l|c|c|c|}
\hline \multicolumn{1}{|c|}{ Вид } & Центр & Контроль & Екотон \\
\hline Limnephilus rombicus & 37 & 6 & 27 \\
\hline Limnephilus flavicornis & - & 10 & - \\
\hline Limnephilus griseus & - & 7 & 3 \\
\hline Potamophylax rotundipennis & 14 & 1 & 3 \\
\hline Grammotaulis nitidus & 5 & - & - \\
\hline Glyphotaelius pellucidus & 6 & - & - \\
\hline Rhyacophila nubila & - & 2 & - \\
\hline Anabolia brevipennis & - & 3 & 3 \\
\hline Halesus digitatus & 3 & - & 36 \\
\hline Ironoquia dubia & - & - & - \\
\hline Paзом & 65 & 29 & \\
\hline
\end{tabular}

У контролі під наметом лісу трапляються шість видів: Limnephilus rombicus, Limnephilus flavicornis, Limnephilus griseus, Potamophylax rotundipennis, Rhyacophila nubila, Anabolia brevipennis, серед яких лише в цьому біотопі відзначено чотири види. Загалом у контролі зібрано найменшу кількість особин $-22,3 \%$.

У екотоні - на межі лісу й галявин - зареєстрували лише чотири види: Limnephilus rombicus, Potamophylax rotundipennis, Grammotaulis nitidus, Ironoquia dubia, серед яких останній вид виявлено тільки в цьому біотопі. В екотоні відловлено 27,7 \% від зібраних особин. 
Отже, найбільша кількість видів (60\%) трапляється в контролі, а найменша (40\%) - в екотоні. Найбільшу кількість особин різних видів зібрали в центрі (50 \%), а найменшу (22,3 \%) - у контролі.

Проаналізовано залежність поширення та чисельність волохокрильців від висоти місцевості над рівнем моря (табл. 3). Установлено, що в ділянках 2, 5, 11 та 15 імаго волохокриців не зареєстровані. Імаго Limnephilus rhombicus, Potamophylax rotundipennis, Limnephilus griseus простежені на різних висотах. На висотах 500-600 м над рівнем моря трапляються Rhyacophila nubila i Anabolia brevipennis. Вид Rhyacophila nubila буває лише на цій висоті. На висотах від 710 до 800 м поширені Limnephilus flavicornis, Ironoquia dubia, Glyphotaelius pellucidus, Halesus digitatus та Grammotalius nitidus. Серед них види Ironoquia dubia та Halesus digitatus зареєстровані лише на цій висоті. Незначну кількість видів відзначено на середніх висотах (від 610 до 700 м) території. Дослідження свідчить скоріше про малі вибірки зібраного матеріалу, ніж про відсутність волохокрильців на цій висоті.

Щодо кількості особин імаго, зібраних на різних висотах (рис. 5), то, як свідчить лінійна лінія тренду, зі збільшенням висоти ділянок над рівнем моря кількість зібраних волохокрильців збільшується. Зокрема, на висотах від 500 до 600 м зібрано 23,8 \% від загальної кількості імаго, на 610-700 м - 37 \%, а на $710-800$ - 39,2 \%. Однак не варто забувати, що висоти від 700 до 800 м над рівнем моря домінують на території дослідження й саме на цих висотах розміщено більшість ділянок дослідження (11 із 20), тому саме на цих висотах і зібрано найбільшу кількість особин.

Таблиия 3

Чисельність волохокрильців на різних висотах та різній експозиції схилів досліджуваних ділянок

\begin{tabular}{|c|c|c|c|c|c|c|}
\hline $\begin{array}{l}\text { № } \\
\text { 3/II }\end{array}$ & $\begin{array}{c}\text { Висота над рівнем } \\
\text { моря } \\
\end{array}$ & Вид & Пн & Пд & $\mathbf{C}$ & 3 \\
\hline 1 & 500 & Limnephilus rhombicus & & 6 & & \\
\hline 16 & 550 & $\begin{array}{l}\text { Limnephilus rhombicus, Potamophylax } \\
\text { rotundipennis, } \\
\text { Limnephilus griseus, } \\
\text { Rhyacophila nubila, } \\
\text { Anabolia brevipennis, }\end{array}$ & & & & $\begin{array}{l}13 \\
2 \\
3 \\
2 \\
3\end{array}$ \\
\hline 3 & 630 & Limnephilus rhombicus & & 2 & & \\
\hline 4 & 670 & $\begin{array}{l}\text { Limnephilus rhombicus, Potamophylax } \\
\text { rotundipennis }\end{array}$ & & $\begin{array}{l}2 \\
2\end{array}$ & & \\
\hline 17 & 700 & Limnephilus rhombicus, & & & & 4 \\
\hline 6 & 720 & $\begin{array}{l}\text { Limnephilus rhombicus, } \\
\text { Potamophylax rotundipennis, } \\
\text { Limnephilus flavicornis }\end{array}$ & & & $\begin{array}{l}1 \\
2 \\
3\end{array}$ & \\
\hline 12 & 720 & $\begin{array}{l}\text { Limnephilus rhombicus, Grammotalius nitidus, } \\
\text { Potamophylax rotundipennis, } \\
\text { Ironoquia dubia }\end{array}$ & & $\begin{array}{l}2 \\
6 \\
7 \\
3 \\
\end{array}$ & & \\
\hline 7 & 730 & $\begin{array}{l}\text { Glyphotaelius pellucidus, } \\
\text { Potamophylax rotundipennis, }\end{array}$ & & & $\begin{array}{l}3 \\
1 \\
\end{array}$ & \\
\hline 18 & 730 & $\begin{array}{l}\text { Limnephilus rhombicus, } \\
\text { Halesus digitatus, } \\
\text { Limnephilus griseus, } \\
\text { Limnephilus flavicornis }\end{array}$ & $\begin{array}{l}6 \\
3 \\
2 \\
1\end{array}$ & & & \\
\hline 19 & 740 & $\begin{array}{l}\text { Limnephilus rhombicus, } \\
\text { Limnephilus griseus, } \\
\text { Potamophylax rotundipennis, }\end{array}$ & $\begin{array}{l}2 \\
2 \\
2\end{array}$ & & & \\
\hline 8 & 750 & Potamophylax rotundipennis, & & & 1 & \\
\hline 20 & 750 & $\begin{array}{l}\text { Limnephilus rhombicus, } \\
\text { Limnephilus flavicornis }\end{array}$ & & $\begin{array}{l}3 \\
1 \\
\end{array}$ & & \\
\hline 14 & 760 & Limnephilus rhombicus & & & & 2 \\
\hline
\end{tabular}


РОЗДІЛ ІІ. Зоологія. 12, 2015

Закінчення табличі 3

\begin{tabular}{|c|c|l|c|c|c|}
\hline $\mathbf{9}$ & \multirow{2}{*}{770} & $\begin{array}{l}\text { Limnephilus rhombicus, Potamophylax } \\
\text { rotundipennis, }\end{array}$ & & 10 & 2 \\
& Grammotalius pellucidus & 3 & \\
\hline \multirow{10}{10}{} & 800 & Limnephilus rhombicus, Grammotalius nitidus, & & 12 & \\
& & Limnephilus flavicornis & 2 & \\
\hline $\mathbf{1 3}$ & 800 & Limnephilus rhombicus & & & 4 \\
\hline
\end{tabular}

Примітка. Пн - північ, Пд - південь, С - схід, 3 - захід.

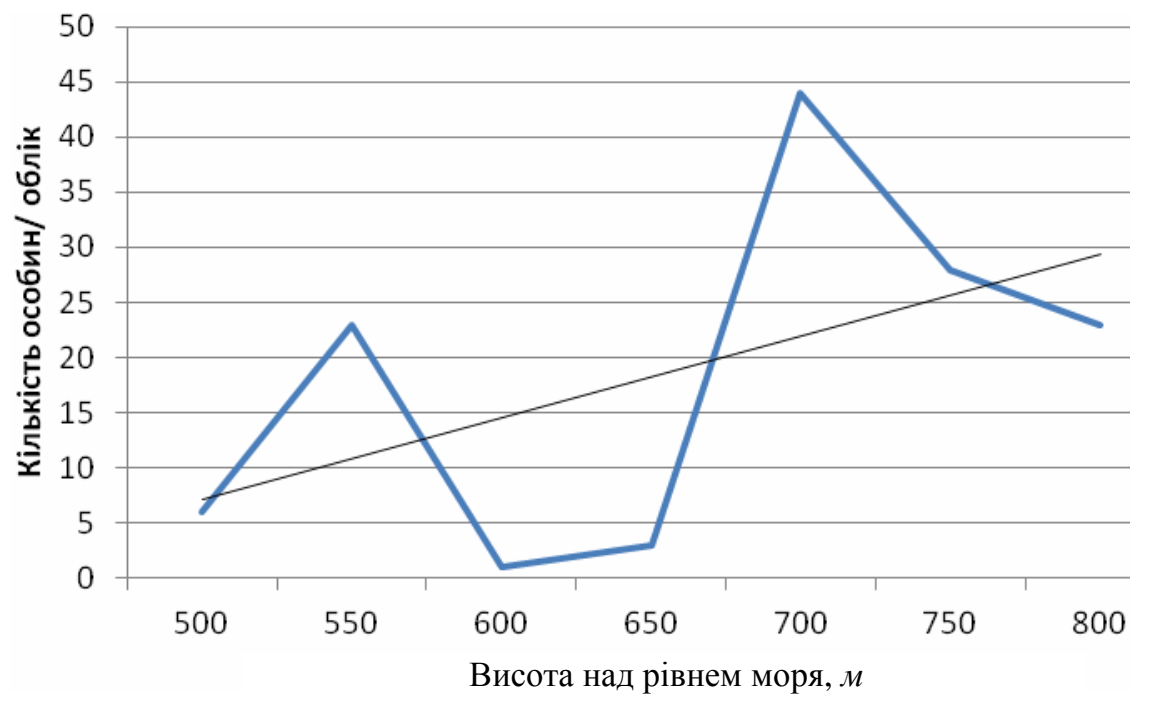

Рис. 5. Чисельність волохокрильц̧ів Угольського заповідного масиву відповідно до висоти розміщення ділянок із зазначенням прямої лінї тренду

Для усунення цієї диспропорції проаналізовано середні показники кількості зібраних особин відповідно до висоти місцевості над рівнем моря. На висотах від 500 до 600 м зареєстровано п’ять видів і зібрано в середньому 15 особин імаго в пробі, на 610-700 м - два види й три особини, а на 710-800 м - вісім видів і в середньому по вісім особин у пробі. Отже, найбільшу кількість видів відзначено на висоті 710-800 м над рівнем моря, а найбільшу кількість особин у середньому зареєстровано на висотах від 500 до 600 м над рівнем моря. Отже, зі збільшенням висоти видове багатство зростає, а кількість зібраних особин зменшується.

Аналіз результатів щодо експозиції схилу показав таке (табл. 3). На північних схилах розміщено дві пробні площі. Виявлено п’ять видів, серед яких Halesus digitatus трапляється лише тут. Загальна кількість зібраних особин дорівнює 18, а середня - дев'ять. На південних схилах розміщувалося п'ять пробних площ, на яких відзначено п'ять видів, серед яких Ironoquia dubia трапляється лише тут. Загальна кількість зібраних особин дорівнює 34, а середня - сім. На східних схилах розміщено п’ять пробних площ, на яких зареєстровано п'ять видів, серед яких Rhyacophila nubila трапляється лише тут. Загальна кількість зібраних особин дорівнює 45, а середня - дев' ять. На західних схилах розміщено чотири пробні площі. Тут зафіксовано п’ять видів. Загальна кількість зібраних особин дорівнює 33, а середня - вісім. Отже, експозиція схилу впливає здебільшого на видовий склад імаго волохокрильців, оскільки три види зареєстровано лише при певній експозиції схилу. Щодо чисельності особин на схилах різної експозиції, то розбіжності незначні (у середньому від семи до дев' яти особин), тому можна припустити, що цей фактор несуттєво впливає на кількість імаго.

Висновки й перспективи подальших досліджень. За попередніми результатами досліджень, на території Угольського заповідного масиву Карпатського біосферного заповідника зареєстровано 10 видів волохокрильців із восьми родів. Домінантний і розповсюджений - Limnephilus rhombicus. Імаго волохокрильців активно літають із квітня до середини серпня. Найвищу активність льоту 
зареєстровано від середини квітня до початку червня. Упродовж решти вегетаційного сезону імаго трапляється в невеликій кількості. Найбільше видів (60 \%) спостерігали в лісі, а найменше (40 \%) - на межі лісу та вікна. Найбільшу кількість особин різних видів зареєстровано в центрі вікна (50 \%), а найменшу $(22,3 \%)$ - у лісі. Зі збільшенням висоти ділянок над рівнем моря зростає видовий склад, а чисельність зібраних імаго знижується. Експозиція схилу впливає на видовий склад імаго волохокрильців, три види (Halesus digitatus, Ironoquia dubia, Rhyacophila nubila) зареєстровано лише при певній експозиції.

\section{Джерела та література}

1. Балог А. Я. Экологическая характеристика ручейников (Trichoptera) Закарпатской области / А. Я Балог // Экология насекомых и других наземных беспозвоночных Советских Карпат : материалы межвуз. конф. (октябрь 1964 г.). - Ужгород, 1964. - С. 7-9.

2. Данко Н. Н. Видовой состав ручейников верхнего Днестра / Н. Н. Данко // Экология и таксономия насекомых Украины. - Киев ; Одесса : Выща шк., 1989. - С. 71-73.

3. Данко Н. Н. Новые и редкие виды ручейников для фауны СССР / Н. Н. Данко // Latvijas Entomologs. 1989. - Вып. 32. - С. $43-47$.

4. Данко Н. Н. Фауна ручейников Украинских Карпат и Прикарпатья / Н. Н. Данко // Latvijas Entomologs. 1988. - Вып. 31. - С. 69-77.

5. Лепнева С. Г. Ручейники / С. Г. Лепнева // Фауна СССР. - Т. 2, ч. 1. - М. ; Л. : Наука, 1964. - 560 с.

6. Лепнева С. Г. Ручейники / С. Г. Лепнева // Фауна СССР. - Т. 2, ч. 2. - М. ; Л. : Наука, 1966. - 560 с.

7. Belke G. Rys historyi Kamienca podolskiego / G. Belke. - Warszawa, 1859. - 158 s.

8. Dziedzielewicz J. Wykaz owadow siatkoskrzydtych (Neuroptera) / J. Dziedzielewicz // Sprawczdanie Komisyi Fiziograficznej. - Krakow, 1867. - T. 1. - S. 158-165.

9. Dziedzielewicz, J. Wiciwczki po Wschodnich Karpatach / J. Dziedzielewicz. - Krakow, 1877. - 40 s.

10. Dziedzielewicz, J. Sieciowki (Neuroptera) zebrine w okolyciach Kolomyji i nad Dnistrem w r. 1882 / J. Dziedzielewicz // Sprawozdanie Komisyi Fiziograficznej. - Krakow, 1883. - T. 17. - S. 244-252.

Сухомлин Екатерина, Чумак Василий, Омелянчук Анна. Анализ видового состава имаго ручейников (Trichoptera) Угольского заповедного массива Карпатского биосферного заповедника. В Угольском заповедном массиве Карпатского биосферного заповедника зарегистрировано 10 видов ручейников с восьми родов. Доминантным и распространенным является Limnephilus rhombicus. Имаго ручейников активно летают с апреля до середины августа. Самая высокая активность лета зарегистрирована в середине апреля и продолжается до начала июня. В течение остального вегетационного сезона численность имаго невысокая. Наибольшее количество видов $(60 \%)$ встречается в лесу, а наименьшее (40 \%) - на границе леса и окна. Наибольшее количество особей различных видов зарегистрировали в центре окна (50 \%), а наименьшее $(22,3 \%)-$ в лесу. С увеличением высоты над уровнем моря растет видовой состав, а численность собранных имаго снижается. Экспозиция склона влияет на видовой состав имаго ручейников. Так, Halesus digitatus зарегистрированы только на северных склонах, Ironoquia dubia - на южных, Rhyacophila nubila - при восточной экспозиции склона.

Ключевые слова: Trichoptera, видовое разнообразие, распространение, Угольский заповедный массив, Карпатский биосферный заповедник.

Sukhomlin Katheryna, Chumak Vasyl', Omeljanchuk Anna. Analysis of Caddisfly (Trichoptera) Imago Species Composition Uholka Reserve Area of Carpathian Biosphere Reserve. Within Uholka reserve area of CBR recorded 10 caddisfly species of 8 families. Dominant and widespread is Limnephilus rhombicus. Imago caddisfly actively flying from April to mid-August. Highest fly activity was registered in mid-April and lasts until early June. During the rest of the growing season imago occur in small quantities. The greatest number of species $(60 \%)$ was occurred in the forest, and the lowest $(40 \%)$ - in the forest and windows. The greatest number of individuals of different species registered in the center of the window $(50 \%)$ and the lowest $(22,3 \%)$ - in the forest. With increasing height above sea level, species composition is growing and the number of imago is reducing. Slope exposure affects the species composition of collected imago caddisfly - Halesus digitatus was registered only on the northern slopes, Ironoquia dubia - on the southern, Rhyacophila nubila was registered only at the eastern slope of the exposure.

Key words: Trichoptera, species diversity, distribution, Uholskyi Reserve array, Carpathian Biosphere Reserve.

Стаття надійшла до редколегії 16.02.2015 p. 